\title{
MANAGEMENT AND FINANCING OF A REGIONAL TOURIST WEBSITE IN THE CONTEXT OF THE REGIONAL TOURISM INFORMATION SYSTEM
}

\author{
EWA GRABIŃSKA
}

\begin{tabular}{l|l} 
& $\begin{array}{l}\text { Jagiellonian University in Cracow, POLAND } \\
\text { e-mail: e.grabinska@uj.edu.pl }\end{array}$ \\
$\begin{array}{l}\text { RECEIVED } \\
\text { ACCEPTED }\end{array}$ & $\begin{array}{l}15 \text { February } 2017 \\
1 \text { May } 2017\end{array}$ \\
JEL & $\begin{array}{l}\text { Z32, Z33, O33, M31 } \\
\text { KEYSSIFICATION }\end{array}$ \\
ABSTRACT & $\begin{array}{l}\text { The aim of this article is to present and discuss the integrated system of information and promotion of tourism in } \\
\text { the region, with particular emphasis on possessing your own website as an effective tool to create a consistent } \\
\text { image of the tourist region. The activities of such a portal are shown from the perspective of management, as } \\
\text { well as of the main problems, in particular funding method. The article highlights contemporary issues and } \\
\text { potential opportunities arising from the needs and demands coming from the market on the basis of an analysis } \\
\text { of the functioning of the Małopolska Tourist Information System and tourist website - www.visitmalopolska.pl. }\end{array}$
\end{tabular}

\section{Introduction}

Tourism is developing in economic dimension having an impact on individual countries, but its effects on regional growth are also immensely strong. The emerging globalization and concentration of supply increase the level of competition and require new marketing methods for destinations. For that reason, many entities responsible for economic progress of regions recognize the growing importance of proper tourist promotion. 
Increasingly regional authorities, noticing the role and significance of tourism, are trying to promote their land using modern tools. In recent years, the Internet has proven to be a powerful tool and an indispensable element in the development strategy and image of the province. The past experience suggests that the most effective system of tourist promotion are travel websites. Therefore, Polish regional authorities take on a number of activities aimed at creating the positive perception of the region, from the tourism perspective, by using specialized internet portals.

\section{The role and significance of the internet tourism portals in the marketing and promotion of regions}

Tourist promotion of the region acquires a fundamental importance, and its effects and scale translate into other economic, political and social activities in the area. It is realized through the use of common marketing instruments, however, all activities related to new technologies deserve particular attention. One crucial market communication channel has been the Internet, as information technology has transformed the tourism industry into a digital economy (Buhalis, Spada, 2000, pp. 41-58). The global network has proved to be a widespread medium and an integral part of the habits of millions of users. An effective online communication strategy is considered nowadays a key element to achieve a competitive advantage on the tourism market. The main benefits that the Internet offers to potential users can be summarized as facilitating the process of decision-making on a purchase based on the assessment of alternative products and offers by service providers (Popesku, 2014, p. 716). Thus, proper use of the regional (voivodeship) tourist information system, as well as modern information technology is fundamental for promoting a development of tourism in the region (Panasiuk, Gardzińska, 2010, pp. 139-154). Tourist information can be served in the one of the following forms: traditional (physical), modern (electronic) and supplementary. Modern (electronic) - by means of electronic media, especially the Internet (including special internet portals, websites of territorial self-government units) (Panasiuk, 2011, pp. 106-115).

All the European countries have implemented some kind of official tourism portal to promote their own destinations (Baggio, 2003 p. 1-12; Han, Mills, 2006, pp. 405-430). One particular class of tourism applications in the Web is Destination Information System (DIS) or Destination Management System (DMS). These systems typically provide information in the Internet about the tourism offerings of a given destinations and may promote e-commerce activities to the potential visitor (Muhammad, Usman, 2010, pp. 81-88). Its development requires extensive cooperation by competing tourism product suppliers and destination promoters in both the public and private sectors (Chen, Sheldon, 1997, pp. 151-176). A properly designed website can serve as the distribution point for all the services facilitating the travellers' planning, helping to ensure they make the right choices and have an enjoyable experience. (Muhammad, Usman, 2010, pp. 81-88).

Also in Poland there are many such portals promoting a particular spatial unit and almost every destination (at the country, state or city level), and providing tourism information online, though, tourist information system is still being organized (see Panasiuk, 2012, pp. 211-223). The following services are in operation on the Polish market for several years: „Magical Krakow” (www.krakow.pl), „Warmia and Masuria” (www.warmia-mazury.pl) and the website of the Malopolskie Voivodeship's official news (www.malopolskie.pl) with a section called "Tourism and Sport", which constitute a sort of compendium of information about the region, tourist attractions, along with links to local government districts and municipalities, and to travel agencies and tourism organizations (Kruczek, Walas, 2004, pp. 215-216). 


\section{The origin and history of the development of the Małopolskta tourism portal}

The Małopolska Tourist Information System (hereinafter referred to as the MSIT) is a modern tourist information system developed in both an analogue, as well as a digital form, established with the support of the EU funds under the Malopolska Regional Operational Programme for 2007-2013 under Priority axis 3. Tourism and culture industry, Activity 3.1. Development of tourist infrastructure and Scheme A. Development of Regional Tourist Information System. The decision to found the MSIT was taken on 17 August 2010, however, the very idea to create such a system in the Malopolska emerged in 2007 after an analysis of the contemporary state of the regional tourist information - inadequate to requirements of the tourist. The biggest problem, though, seemed to be the lack of a regional tourism website offering information from the entire region, because - as it turned out - according to the "Research of tourist traffic in the Malopolskie Voivodeship" almost half of visitors gained knowledge about the region from the Internet. Therefore, the main objective of the development policy of tourism in the area was launching an integrated system of easily accessible tourist information about the region.

\section{Principles and objectives of the operation of the tourism portal www.visit.mlopolska.pl}

Assumptions of the Malopolska Tourist Information System (MSIT) project has been specified in the partnership agreement adopted by the Board of Malopolska Region by Resolution no. 857/2009 857/2009 of 29 July 2009 and in the Rules of functioning and work of the MSIT. The project involved a construction of unified regional tourist information system in the Malopolskie Voivodeship, developed in an analogue (i.e. traditional information) and a digital form, connected by an integrated management system. The priority tasks were, among others establishment of a regional tourism portal, standardization of tourist information (TI) points (unification of customer service, categorization and visualization of TI units); creation of regional TI points and a digital database of tourist information; development of a network of electronic kiosks (info kiosks); implementation of a regional tourist card and system of uniform labelling of tourist attractions; intensification of publishing.

The work on the project started in 2008 with the acquisition of partners (signing of the declaration of participation in the project) and the preparation of feasibility study of the project, and the model of the system. A year later, on 22 May 2009 the Board of Małopolska Region adopted Resolution no. 550/09 approving the rules of implementation of the Malopolska Tourist Information System project, under which a number of activities to be undertaken:

a) in an analogue form:

- establishment of a network of units providing tourist information (including integration of existing points and creation of new ones, unifying standard operation of units through implementation of a system of categorization, visualization, providing equipment for customer service),

- establishment of a labelling system for attractions and areas attractive for visitors (among others by traffic and information signs),

- creation of an integrated system for the promotion and sale of products and tourist offer of the region (including preparation and distribution of free publications and promotional materials for tourist information);

b) in a digital form: 
- creation of an integrated system of gathering, processing and sharing data using the latest technology (including an integration of existing tourist databases and websites, building a regional tourism portal and a network of electronic kiosks available 24/7 - info kiosks, production and distribution of multimedia content),

- implementation of the Malopolska Tourist Card;

c) introduction of a system of training and enhancement of qualifications for the staff employed in TI points, both in analogue and digital parts of the MSIT.

In accordance with provisions of the partnership agreement at analogue level, the implementation of the MSIT assumed preparation by the leader (Małopolskie voivodeship) individual projects arranging an individual TI unit, and the purchase and provision of equipment and signs for TI points, info kiosks, and transferring them to the partner of the project to its ownership.

The implementation of the MSIT project at the digital level was faced with the challenge of creating a digital system, which includes:

a) the MSIT regional web portal www.visitmalopolska.pl, administrated by the Leader (UMWM) and Partners (RCITs, CITs and PITs);

b) local Partners' portals (managed by Partners of the project, i.e. CITs and PITs);

c) database system of the MSIT (database of tourist facilities);

d) document repository (Extranet) managed by the Leader (UMWM) and Partners (RCIT);

e) info kiosks network (administered by CITs and PITs).

Thus, the objective of the digital system of the MSIT was to build the regional tourism portal www. visitmalopolska.pl and local services of the MSIT unified with the regional one, operating in eight languages (Polish, English, French, German, Italian, Russian, Spanish, Slovak), as well as the development of a joint regional base constructed and used by all units integrated within the MSIT. The name of the website was created as a subdomain of the regional portal, according to the formula www.town_name.domain.domain. In order to identify all subdomains, the same layout and navigation system was used, so as potential users intuitively know how to use the service. In both, analogue and digital systems of the MSIT there were three administrative levels involved in three scopes of privileges, where privileges management and their execution is carried out exclusively from the web application (service via web browser).

\section{The financing and the number of partners}

The MSIT is being realised with joint forces of the Małopolskie Voivodeship as the leader of the project and project partners: 25 counties and districts in the Małopolska under the Małopolska Regional Operational Programme for the years 2007-2013.

The scope of privileges and their execution in MSIT Partners' portals were included in the Manual for the Małopolska Tourist Information System and in the Agreement defining terms of cooperation and mutual obligations arising from participation in the Małopolska Tourist Information System (MSIT), which was intentionally created, and which determined the rules of access to the MSIT regional service.

The financing has changed over time, and so the value of the project amounted to PLN 19, 221,533 including co-financing from the MRPO for the years 2007-2013: PLN 14,366,924 (75\%). The contribution of the Małopolskie Voivodeship amounted to PLN 3,588,143 and of the project partners (25 local government units) PLN 1,200,831 
- a total of PLN 4,788,974 (25\%) (www.fundusze20072013.malopolska.pl, access 9.09.2016), of which 75\% of the costs were eligible and $25 \%$ - ineligible costs. The adaptation of TI units to the MSIT standards was planned for two years, but eventually the work was extended to 12 March 2012 and as a consequence financing of the project has been changed either. The total value of the project was PLN 17,299,835.78 (reduction of PLN 19,221,533.43), and the eligible costs amounted to PLN 16,524,038.43 (reduction of PLN 19,155,899.43), and ineligible expenditure PLN 775,797,35 (an increase from PLN 65,634).

Table 1. Partners of the MSIT project

\begin{tabular}{|c|c|c|}
\hline $\begin{array}{l}\text { Kraków subregion: } \\
\text { Municipality of Kraków - } 7 \text { InfoKraków points } \\
\text { Municipality of Myślenice } \\
\text { Municipality of Dobczyce } \\
\text { Municipality of Wiśniowa } \\
\text { Municipality of Miechów } \\
\text { Municipality of Olkusz }\end{array}$ & $\begin{array}{l}\text { Oświęcim subregion: } \\
\text { Municipality of Oświęcim } \\
\text { Municipality of Chrzanów Municipality of Trzebinia }\end{array}$ & $\begin{array}{l}\text { Tatrzański subregion: } \\
\text { Municipality of Zakopane } \\
\text { Municipality of Rabka-Zdrój } \\
\text { Tatrzański District- } 3 \text { TI points } \\
\text { Municipality of Poronin } \\
\text { Municipality of Nowy Targ }\end{array}$ \\
\hline $\begin{array}{l}\text { Tarnów subregion: } \\
\text { Municipality of Tarnowa } \\
\text { Municipality of Dabrowa Tarnowska } \\
\text { Municipality of Tuchów }\end{array}$ & $\begin{array}{l}\text { Wadowice subregion: } \\
\text { Municipality of Wadowice } \\
\text { Municipality of Andrychów } \\
\text { Municipality of Sucha Beskidzka }\end{array}$ & $\begin{array}{l}\text { Beskidzki subregion: } \\
\text { Nowy Sacz City } \\
\text { Municipality of Krynica-Zdrój } \\
\text { Limanowski District } \\
\text { Municipality of Biecz } \\
\text { Municipality of Sękowa }\end{array}$ \\
\hline
\end{tabular}

Source: http://www.visitmalopolska.pl/strony/msit-malopolski-system-informacji-turystycznej-359.aspx.

Table 2. Scheme of administration and privilege of the MSIT system

\begin{tabular}{ll}
\hline \multicolumn{1}{c}{ Administrative level } & \multicolumn{1}{c}{ Scope of privileges } \\
\hline Leader - regional administrator - UMWM / RCIT & The entire system (regional portal, local portals) \\
Partner - local administrator - CIT & Local portal \\
Partner - local administrator - PIT & Local portal \\
User & MSIT regional portal, databases, MSIT local portals, info kiosks \\
\hline
\end{tabular}

Source: Rules of functioning and work of the Małopolska Tourist Information System.

At the same time, according to rules adopted for the projects included in the Indicative list of individual projects due to reduction of eligible costs, the funding for the system has been increased to a level of $85 \%$ of eligible expenditure and amounted to PLN 14,045,432.67.

In 2010, tasks related primarily to the construction and modernization of TI points (partners of the MSIT) were completed for a value of PLN 4,348,266 and 27 individual interior design projects for TI units were realized for PLN 42,000. By the end of the year 2010 information boards (marking of tourist region) were made and installed in the biggest tourist attractions in the region for the amount of PLN 83,506 and the Tourist Service Manual was developed for PLN 49,000. In 2011, the TI units were equipped in furniture, hardware, telecommunications, audio visual and office equipment for the total amount of PLN 3,153,943 (including the authorship supervision for the equipment for TI points for a price of PLN 17,535). Up to the end of the year 2011 signposting of tourist sites was complemented for the total sum of PLN 770,000, the Tourist Service Manual was developed, costs of trainings for the employees of the units were PLN 97,900, the MSIT promotion activities started (promotional campaign, presentations at trade 
fairs, printed publications, certification) for the amount of PLN 4,375,784. At the turn of 2010/2011 the development of information technology system for the MSIT began (database system, visitmalopolska.pl, integration with local portals, IT training) for the sum of PLN 905,000. At the end of the year 2012 work on the project was completed. On 20 November 2012 the Board of Małopolska Region announced an open tender for the execution of tasks associated with maintaining the sustainability and development of the MSIT for a total of PLN 1,212,000 (for the year 2013). In the years 2013, 2014 and 2015 to 2017 the Małopolska Tourist Organisation became the contractor obliged to maintain the project sustainability and development. The total value of the project in accordance with the data for 2016 amounted to PLN 16,539,016.33. The value of eligible expenses was PLN 15,790,070.51, and funding from the EU (85\%): PLN 13,421,559.09 with own input (project leader + project partners): PLN 3,117,457.24.

Taking into account Polish conditions, the scale of financing seems to be impressive, but from the perspective of tasks and challenges related to the operation of this system, as well as in comparison with expenditure incurred for the promotion of tourism by the big players in the international tourism market, this project would require funding.

\section{Conclusions}

In contemporary world it is hard to imagine the smooth functioning on a competitive market of tourist services without the use of modern technologies and marketing tools. Both tourism destinations and enterprises increasingly need to adopt innovative methods and enhance their competitiveness. Timely and accurate information, relevant to consumers' needs is often the key to satisfaction of tourist demand (Muhammad, Usman, 2010, pp. 81-88; Buhalis, 1998, pp. 409-421). It should be emphasized, that the website www.visit.malopolska is trying to respond to changing trends coming from the international market. Especially noteworthy are various products offered by this service (e.g. Małopolska in the camera eye, mobile Małopolska@, Małopolska Railways). Several mobile applications were built, which are guides to hiking trails in the Malopolska (The trail of the January Uprising, The First World War's Eastern Front Trail, Małopolska Traditional Craft Route, Małopolska Countryside for Children, Wooden Architecture Route). A good example is also a mobile application Małopolska Village in the Saddle, developed with financial support from the Małopolskie voidvodeship within the framework of "Małopolska Hospitable". As well as the subpage sacrum.visitmalopolska.pl, which was created as a response to the growing role of religious tourism.

Although, probably the weakest point of the service is its functionality. Unchanged graphic design since the website was set up and the lack of innovation (forum, comments, booking online, newsletter) make it less attractive, and the excess of content introduces unnecessary information chaos, leaving an impression as if the portal was not updated. Another disadvantage is the lack of commitment of project partners (CITs, PITs). They have their own sub portals, and do not engage in updates of the regional web page or even completely ignore it.

The crucial role of local and regional tourism organizations in the creation of this system should therefore not be forgotten (Panasiuk, Gardzińska, 2010, pp. 100-109). It is noticeable, that the involvement of the Małopolska Tourist Organisation can be a good step toward the professionalization of tourism promotion. It needs to be highlighted that the major advantages of the portal are: improvement of the level of tourist services, increase in the number of people using tourist information, balanced presentation of tourist attractions of individual destinations, comprehensive information and increasing accessibility (for people with disabilities), etc. Also it is important that the site is available in eight languages, tailored to the needs of people with disabilities, and allowing sharing via 
Facebook or Twiteer. Thus, the page visitmalopolska.pl is highly positioned in the search engines, and the portal can be an essential tool in promoting the positive image of the region from the perspective of tourism.

The main objective of the project was to build a modern regional tourist information system with integrated analogue and digital levels and to improve tourism competitiveness of the region, adjusting tourist information to the European standards and harmonizing the level of provision of tourist information in the entire province. These goals have been achieved, and after a detailed observation of both management and financial issues, it can be stated that the regional tourism portal for the Małopolska, despite some drawbacks, is one of the most professional regional tourism services in the country. Looking from a global perspective, it is clear that this type of websites, as well as the segment of new marketing technologies are probably in their early stages of development in Poland. They should not, however, be neglected or underestimated, as in near future functioning of the market of tourist services will require innovative activities using modern technology.

\section{Reference}

Baggio, R. (2003). A Websites Analysis of European Tourism Organizations. Available at: http://www.esade.edu/cedit2003/pdfs/ baggiorodolfo.pdf (12.12.2016).

Buhalis, D. (2003). E-Tourism: Information Technology for Strategic Tourism Management. Englewood Cliff s NJ: Prentice Hall.

Buhalis, D. \& Law, R. (2008). Progress in tourism management: Twenty years on and 10 years after the internet: The state of eTourism research. Tourism Management, 29 (4), 609-623.

Buhalis, D. \& Spada, A. (2000). Destination Management Systems: Criteria for Success: An Exploratory. Research Journal Information Technology and Tourism, 3 (1), 41-58.

Buhalis, D. (1998). Strategic use of information technologies in tourism industry. Tourism Management, 19 (5), 409-421.

Chen, H. \& Sheldon, P.J. (1997). Destination Information Systems: Design Issues and Directions. Journal of Management Information Systems, 14 (2), 151-176.

Choi, S., Lehto, X.Y. \& Oleary, J.T. (2007). What Does the Consumer Want from a DMO Website? A Study of US and Canadian Tourists' Perspectives. International Journal of Tourism Research, 9, 59-72.

Han, J. \& Mills, J. E. (2006). Zero Acquaintance Benchmarking at Travel Destination Websites: What is the First Impression that National Tourism Organizations Try to Make? International Journal of Tourism Research, 8, 405-430.

Kruczek, Z. \& Walas, B. (2004). Promocja i informacja turystyczna. Kraków: Proksenia.

Law, R., Qi, S. \& Buhalis, D. (2010). Progress in tourism management: A review of website evaluation in tourism research. Tourism Management, 31, 297-313.

Muhammad, A.S. \& Usman, G. (2010). Destination information management system for tourist. GESJ Computer Science and Telecommunications, 6 (29), 81-88.

Panasiuk, A. \& Gardzińska, A. (2010). Informacja turystyczna. Warszawa: C.H. Beck.

Panasiuk, A. (2011). The problems of tourist information system management in west-pomeranian region. Journal of Economics \& Management, University of Economics in Katowice, 7, 106-115.

Panasiuk, A. (2012). Chosen problems of tourist information system management on the example of west pomeranian voivodeship's municipalities. Zeszyty Naukowe Uniwersytetu Szczecińskiego, Scientific Journal. Service Management, 8, 211-223.

Popesku, J. (2014). Social Media as a Tool of Destination Marketing Organizations (pp. 715-721). Singidunum University, Serbia. Available at: http://portal.sinteza.singidunum.ac.rs/Media/files/2014/715-721.pdf (13.12.2016).

Resolution No. 550/09 of Małopolska Tourist Information System MSIT, 22 May 2009.

Wang, Y. \& Pizam, A. (eds.) (2011). Destination Marketing and Management: Theories and Applications. London: Oxfordshire, CAB, UK. http://bip.malopolska.pl.

http://ww.visitmalopolska.pl. 